Article

\title{
Project-Based Governance Framework for an Agri-Food Cooperative
}

\author{
Ana Teresa Herrera-Reyes ${ }^{1, *(1)}$, Ignacio de los Ríos Carmenado ${ }^{2}$ (D) and Jesús Martínez-Almela $^{3}$ \\ 1 Agroforestry Engineering Department, Higher Technical School of Agronomic, Food and Biosystems \\ Engineering, Polytechnic University of Madrid (UPM), 28040 Madrid, Spain \\ 2 Research Department, School for Industrial Organization (EOI), 28040 Madrid, Spain; \\ irioscarmenado@learning.eoi.es \\ 3 Bioagroprojects Biotech PPM, 12540 Villarreal, Spain; jma@bioagroprojects.com \\ * Correspondence: anateresah@gmail.com or anateresa.herrera@alumnos.upm.es; Tel.: +34-693-232-270
}

Received: 30 March 2018; Accepted: 31 May 2018; Published: 5 June 2018

\begin{abstract}
In a context that approaches the limits of environmental and social problems, and in view of the challenges that the agri-food sector faces today, the need to produce more food, linking environmental sustainability and human health, constitutes a means for sector organizations to turn these new conditions into opportunities to achieve their strategic objectives in project governance. The objective of this study is to analyze the governance of an agri-food cooperative comprised of farmers with more than 40 years of experience. In addition, we propose, based on the findings obtained, a plan for the organization to integrate the culture of the projects and project management in its governance system. This paper is based on a conceptual framework that takes into account the systemic nature and dynamics of social and organizational interactions, with the aim of moving towards sustainability within the agri-food system, through the analysis of an empiric study in the agriculture cooperative sector in the southeast of Spain. The findings show that working by projects offers a novel and effective governance model for the sector, and that integrating expert and experienced knowledge, working with people, is a fundamental condition for moving towards sustainability.
\end{abstract}

Keywords: agri-food; cooperative; project management; organizational competences; project-based governance

\section{Introduction}

The agri-food sector is moving towards an era of rapid market changes, where technological, social, and environmental circumstances often develop unpredictably [1]. The need to produce more food with guaranteed safety while respecting the environment represents a major challenge for the agri-food sector and agribusiness [2], but also offers unprecedented opportunities for diversification and value addition due to the nature and scope of the changing structure of demand [3].

Such circumstances lead to the need to orient the agri-food system (AS) towards sustainability [4], which requires innovative approaches in infrastructure, organization, production, distribution, and product offerings [5]. Still, it must always kept in mind that organizations will only be sustainable if they are competitive in terms of costs, prices, operational efficiency, supply of products, and other associated parameters, and only if the remuneration received by farmers is profitable. This is a particular challenge for small and medium enterprises in the sector and for small farmers, who, in order to maintain competitiveness, must be able to deliver products in greater quantity and of better quality [3]. 
In this context, there is a need to increase the number of projects that must be carried out simultaneously along the entire agri-food chain, as well as new forms of government. The literature emphasizes that organizational, social, and technical innovations are needed to take the path towards sustainability [6,7], introducing project-based governance [8,9] as a strategy to respond to the new circumstances and demands of a market that is in constant change and tends to be increasingly competitive.

Currently, project-based governance is understood as a form of government that fulfils two characteristics: it achieves the strategic objectives of the organization through projects, programs, and portfolios (PPP), and it maintains a continuous development of organizational competences in project management (OCPM) [10,11]. Wagner (2012) defined OCPM as "an organization's internal capability of achieving its targets by smartly combining, applying, managing and developing its available individual, strategic, structural and cultural competences as well as its assets when performing project work" (p. 50). Strategic competence refers to the ability to develop a strategy to align the PPP with the corporate strategy. The structural competences are related to the inherent processes, routines, functions, and responsibilities generally described in the standards and applied through projects and programs. Cultural competence is related to the culture based on projects that show the corresponding personnel, and it is part of the corporate culture with its beliefs, values, and behaviors. Finally, assets are understood as all tangible and intangible resources for project work [10]. In this conceptual framework, projectification is understood as the process of the transformation of an organization towards project-based governance, from the organization of the work of the functional areas through projects and the various organizational changes that accompany it [12].

In the field of agri-food and rural development organizations, the Working With People (WWP) model is presented as a conceptual proposal to address project-based governance from three dimensions: political-contextual, technical-business, and ethical-social [13]. This proposal is the result of 25 years of experience working with organizations that implement projects in rural areas, in European contexts, and in emerging countries, and incorporates elements of organizational learning [13-19] and project management (PM) models that prioritize behavioral [20-22] and contextual [23-26] competences. In addition, the WWP model aims to overcome the merely technical aspects of project-based governance, promoting organizational development with an ethical basis [13] to contribute to sustainability [27].

The need to orient the SA towards sustainability has been recognized in recent years by research, society, and industry [4]. Although the definition of sustainability is still in dispute and evolution, due to the different philosophical interpretations of each of its dimensions [28-30], there is agreement that it comprises three dimensions that are necessary to balance: environment, economy, and society [28]. There is also a consensus that farmers, as "authentic guardians" of the AS, have an important role in the sustainability of the food chain [31]. Therefore, cooperatives in the sector, individual companies, and farmers are all relevant actors to design initiatives that contribute address the challenges of sustainability $[32,33]$.

On the other hand, due to the holistic, diverse, and distinctive nature of agri-food organizations, in the transition towards a more sustainable agriculture, new forms of knowledge and learning that integrate social and environmental values are required [34-39]. In this paper, we explore the relevance of farmers' knowledge and social learning practices in the construction of alternative pathways in sustainable agriculture and the strengthening of project-based governance. According to the WWP model, the common action occurs through the planning of social learning in an organization, by retaining the memory and the continuity of actions to carry them out through dialogue, teamwork, and community projects. From a project-based governance framework, WWP is understood as the professional team practice that seeks to connect knowledge and action through a common project management, which, besides the technical value of production (of goods and services), mainly incorporates the value of the people who participate and contribute to development in the context of the project [13]. 
The collective management strategy, together with a constant flow of knowledge and learning (both formal and informal), are the two key elements that contribute to address project-based governance from the three WWP dimensions and to create more sustainable and prosperous rural areas $[40,41]$. The specific characteristics of the WWP model in agri-food organizations have been described in numerous investigations [13-19,27,40-42], and these add some new elements to the organizational competences in project management presented in this work.

The general objective of this research is to analyze the way in which an agri-food cooperative is governed with farmers with more than 40 years of experience, as well as to propose, based on the findings obtained, a plan for the organization to integrate the culture of the projects and project management in its governance system. It is based on the following hypothesis: project-based governance can contribute to the sustainability of the AS, helping agri-food cooperatives to define a governance model that allows them to face the challenges of the current context and achieve their strategic objectives, to defend their position in the market, and to be sustainable.

To analyze this hypothesis and determine the elements that the governance framework should include, we proceeded to study the characteristics presented on the PM and the WWP in the Agrarian Transformation Society (ATS) Camposeven, analyzed from the OCPMs proposed by the OCB-Organizational Competence Baseline (2016) of the International Project Management Association-IPMA [11], as well as the dimensions covered by the WWP.

\section{Materials and Methods}

\subsection{Case Study: Agri-Food Cooperative}

We based our paper on the case study carried out in the international Rethink research project (Visit: http:/ / www.rethink-net.eu) (2013-2015), supported by the European Commission and funding bodies in 14 countries under the umbrella of FP7 and the RURAGRI ERA-NET. The research members of Rethink formed a multi-sectorial and interdisciplinary expert panel to provide research advice on sustainable strategies and ways to develop rural prosperity based on the WWP governance conceptual framework [13]. The WWP governance model integrates experiential and expert knowledge and connects knowledge to action, incorporating the values of the people involved with the importance of the flow of goods and services generated in any project, and aligning with corporate and business strategies. Moreover, the WWP model provides a rich social context in which to explore how cooperatives and companies move from the corporate level to program and project strategy $[15,16]$. In the framework of Rethink, one of the case studies was the ATS Camposeven, which is located in the region of Murcia, Spain (Figure 1).

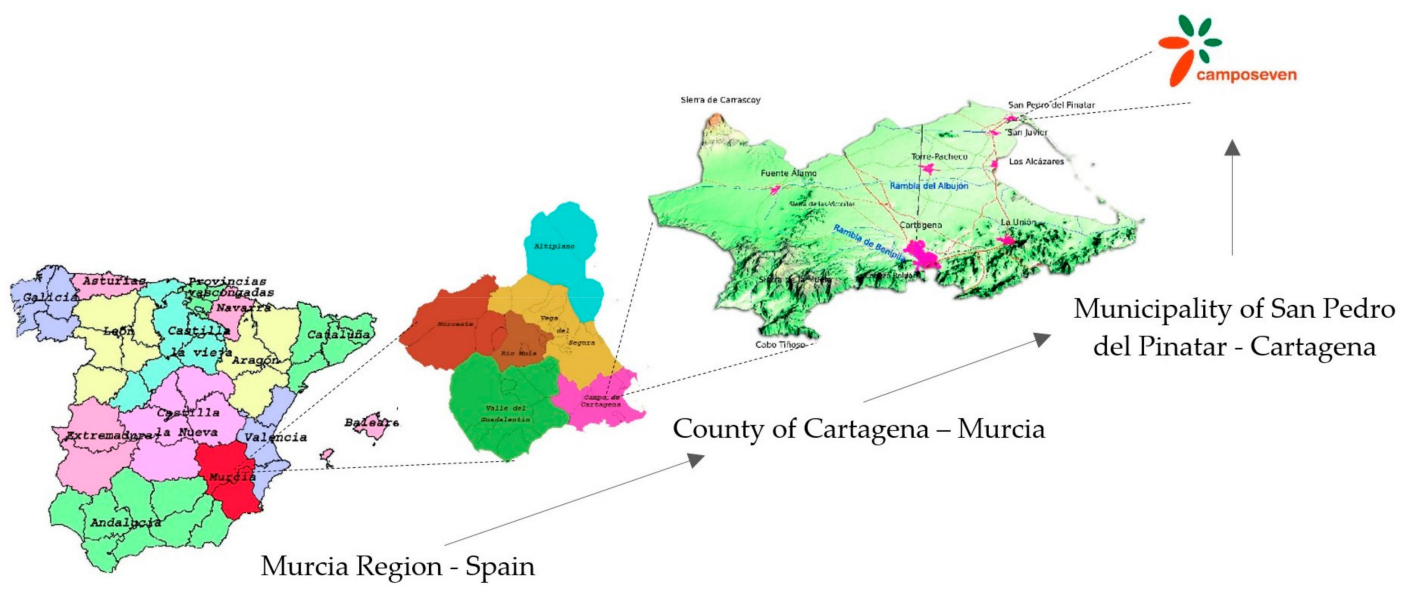

Figure 1. Spatial context of the investigation. 
The stakeholders' behavioral competence, as well as the solid ethical foundations, are considered key elements in this governance model, together with technical and contextual competences, which are necessary to develop projects that align with the cooperative strategy using social and associative processes $[15,40,42]$. This human vision of project-based governance in the agri-food cooperative sector was agreed upon by the expert panel as the ideal method for the sustainability and rural prosperity established in the analytical framework [41].

The ATS is an agrarian associative form of the Spanish legal system [43], having an associative and personalist nature [44]. Both the ATS and the cooperatives represent associative agri-food entities in Spain, as well as being social economy enterprises that, as such, contribute to fostering regional development and rural employability [45] from a business perspective [46].

The ATS Camposeven handles projects informally, using efforts and resources from a strategic vision that highlights the interest in integrating project-based governance. The management team, in 2008, participated in a PM training plan and the chief executive officer (CEO), himself, is certified in IPMA Level B. The ATS was founded in 2007 by seven producing families, which today includes 37 members, with more than 40 years of experience in the production, transformation, and commercialization of horticultural, organic, and conventional crops in the region of Murcia. Together, they have a cultivated area of 1368 hectares, of which 788 hectares are organic, 480 are biodynamic, and 100 are conventional production, since they are still in the process of converting all their production to ecological and biodynamic crops. This ATS has the following characteristics that make it especially interesting from the point of view of the research objectives: (1) it promotes social learning processes between the parties involved (organic producers, companies, research organizations, and local and regional governments) towards the ecological culture and the sustainability of the AS; (2) it is considered a successful associative governance experience in the organic farming sector; (3) is has an innovative business strategy recognized with different national and international awards; and (4) it has different university-business alliances to promote research, development and innovation (R\&D\&I) projects in relation to the sustainability of the AS.

\subsection{Research Design, Collecting Data Technique, and Participant Selection}

Based on a literature review, an interview script was designed to integrate knowledge from the ATS, and the methodological procedure is presented in Figure 2.

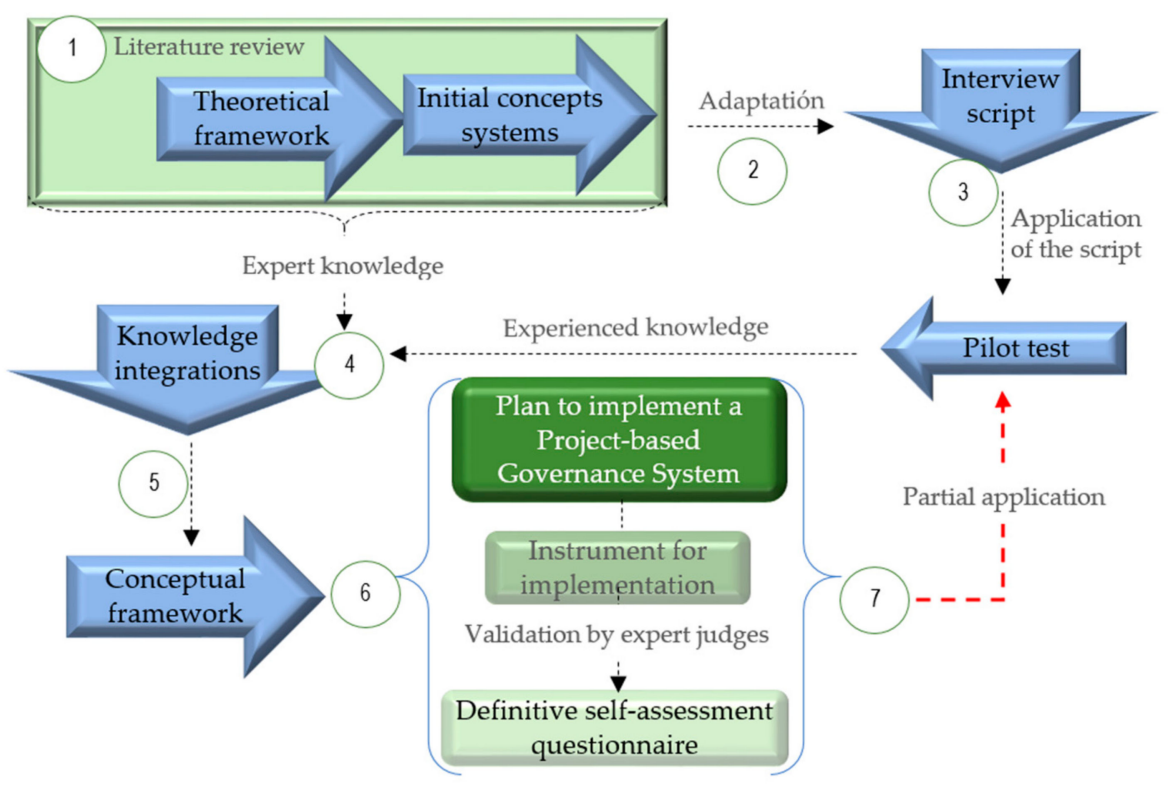

Figure 2. Methodological procedure for plan design. 
It is an investigation with qualitative methodology, using semi-structured interviews as a technique for collecting data. For the design of the interview script, the IPMA OCB [11] was used as an internationally-recognized standard that provides the basis for the OCPM, in addition to a series of operational questions for each of the areas and elements of competences. In the WWP case, questions were designed and validated by an expert panel formed by 38 researchers from the 14 European Union countries participating in the Rethink Project $[39,47]$. Twenty-nine people were comprehensively interviewed, including all members of the governing board (seven), the directors and middle management (10); other members involved (six), and suppliers and partner companies (six).

\subsection{Process of Data Collection, Ethics, and Quality Protocol}

The interviews were conducted at the organization's facilities. Starting from the ethical principle that the people who participate must do so freely and voluntarily [48], before the consent of confidentiality was signed, the purpose of the interview was communicated to them and they were informed that they could refrain from answering when they considered relevant. In the development, any type of useful documentation was requested. The interviews were recorded on audio, then transcribed into a text document. To facilitate the process of transcription, the computer program F4transkript (version 3) was used (Visit: https://www.audiotranskription.de/english/f4.htm). The transcripts were entered into a specific computer program for the analysis and processing of qualitative data (MAXQDA, version 12) (Visit: http://www.maxqda.com), minimizing internal inconsistencies and allowing greater precision.

\subsection{Analytical Approach and Analysis Plan}

In order to guarantee the excellence of the coding [49], starting from the thematic areas defined [50] (OCPM and WWP), the analytical approach was based on a cyclical strategy of content analysis, through the coding and categorization of the data, grouping into families of codes those that share properties and characteristics [51]. In the first cycle, we proceeded to carry out a broad coding of the entire system. The second and third cycles focused on the detail of each thematic area, grouping and creating categories according to the concurrence of the codes. Memos were also written, which are notes with critical reflections on the process [51,52]. Finally, in the fourth cycle, the thematic areas were integrated, resulting in a series of dimensions that the analyzed cooperative should include in its governance system, with a project-based approach to achieve the global sustainability of the organization. To define the elements and characteristics of each dimension, the identified strengths and weaknesses were integrated [51,53]. These dimensions were integrated in Phase II of the plan, as presented below.

\section{Plan for the Implementation of a Project-Based Governance System}

Once the dimensions were defined, and following the recommendations for the development of the OCPM of IPMA OCB and its support tool IPMA Delta [11], as well as the contribution of Wagner (2012) [10], we proceeded to define the phases that will help to implement a project-based governance system in the agri-food cooperative analyzed.

- Phase I. Analyzing the context of the organization. This phase is about defining the organization and analyzing the context in which the business operates: what it does, the vision, the mission, its history, as well as the description of the cultural, social, and economic context, etc. This will allow the establishment of those aspects that, after evaluating the current situation of the organization, will help to decide where it wants to go.

- Phase II. Evaluating the current situation of the organization regarding the dimensions identified (Figure 3), related to the application of the OCPM and the integration of strategic initiatives that contribute to the sustainability of the AS. Determining its current situation will reveal where the 
organization is by identifying the strengths of the governance system and, more importantly, by identifying the weaknesses that must be resolved in order to evolve.

- Phase III. Defining where the organization wants to go and the level of competence that it wants to achieve. Based on this, the strategy to achieve it must be defined.

- Phase IV. Reviewing the mission and vision, making the changes of place to integrate the role of the projects. Next, the strategy must be reformulated, establishing clear objectives for the PM.

- Phase V. Proceeding to organizational alignment. According to the IPMA OCB [11], this phase is about: (1) aligning the projects with the processes of the operations that are carried out in the organization; (2) aligning the functions that the projects entail within the existing organizational structure; and (3) integrating the project approach in the culture of the people, through awareness-raising activities, training, certification, etc.

- Phase VI. Maintaining the continuous development of the OCPM. This is related to planning and undertaking the necessary actions to remain up-to-date and ensure the continuous development of the OCPM, which depends on the ability of the organization to undertake new business and respond to changing context conditions [11].

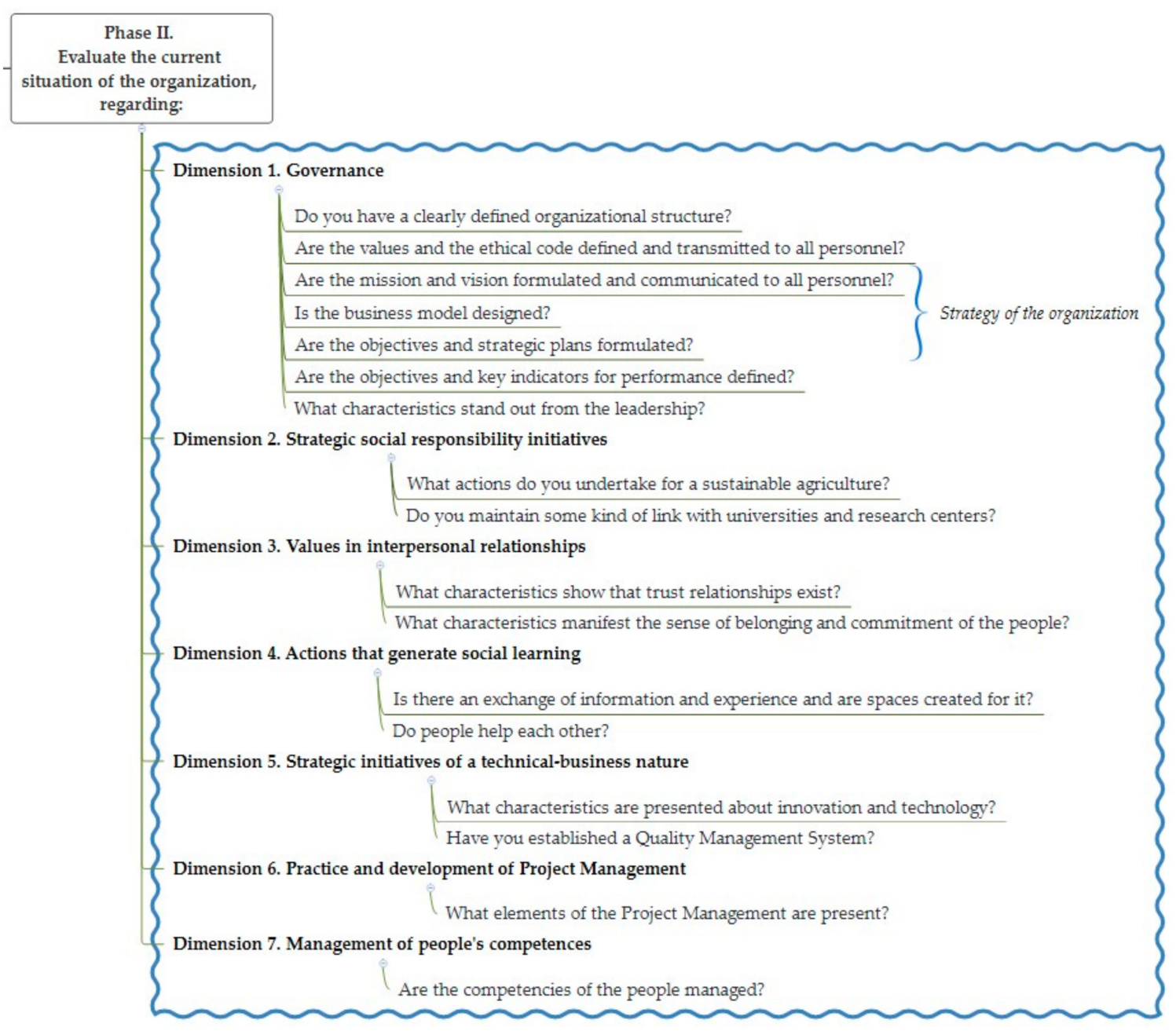

Figure 3. Phase II of the plan and the dimensions to be evaluated.

Defining the phases of the implementation of the project-based governance system, Figure 4 shows the structure of the plan to be followed, which is understood as a tool to guide the process of projectification of the cooperative. 
Next, the results and discussion of the pilot test that contributed to the design of the plan and that represent Phase II of the plan are presented, describing, in turn, each of the dimensions involved.

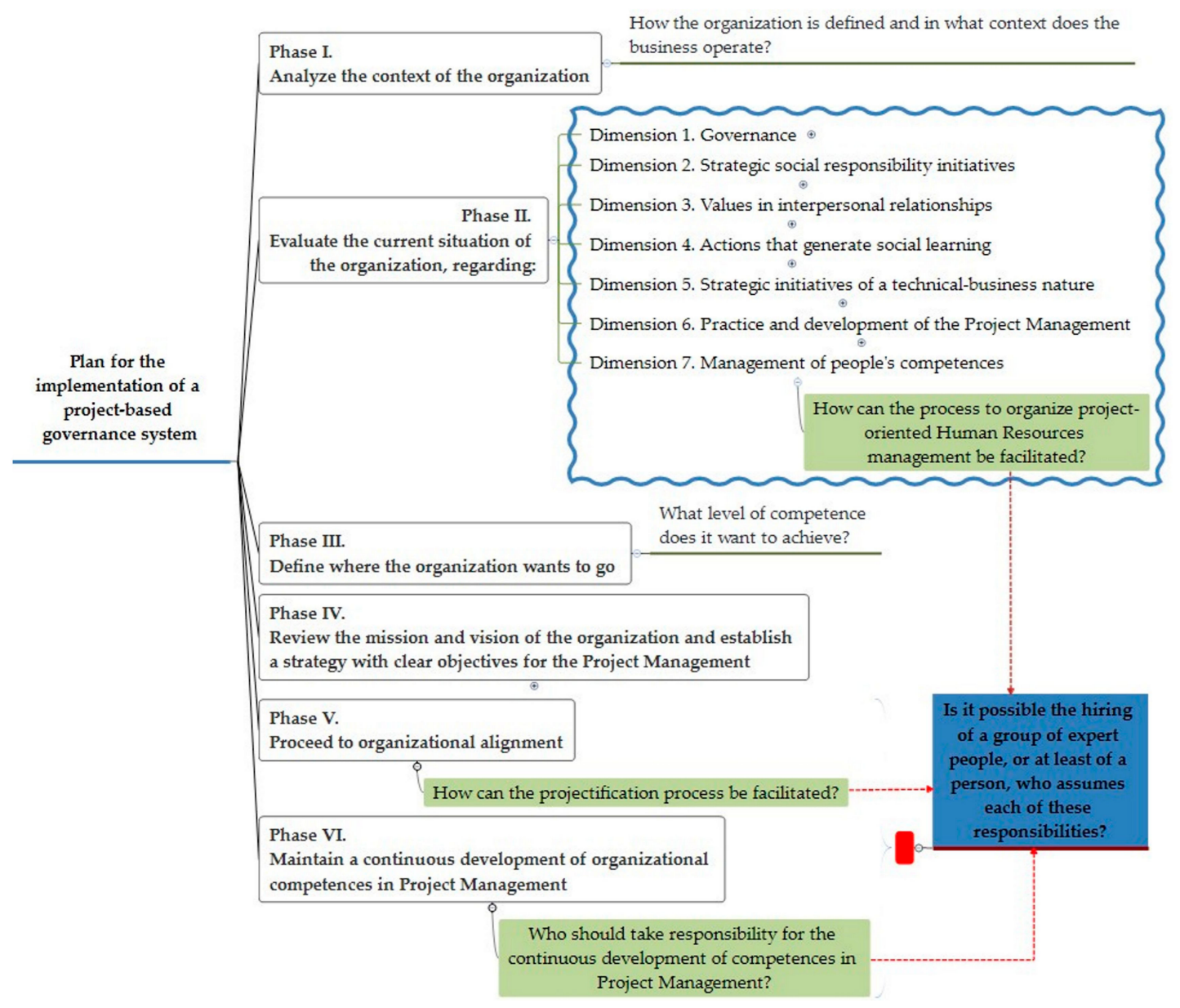

Figure 4. Plan for the implementation of a project-based governance system in the agri-food cooperative.

\section{Results and Discussion}

\subsection{Dimension 1: Governance}

The establishment of a governance system is a basic element to provide strategic guidance to the organization. The results of the review and analysis of the data show that it must include the following elements: the structure of the organization, the values and the code of ethics, the mission and vision, the business model, the objectives and strategic plans, the objectives and indicators for performance, and the appropriate style of leadership.

\subsubsection{The Structure of the Organization}

For an organization to be operational, it must establish its organizational structure, and if it is of an associative nature, the results of the analysis indicate that it is fundamental to clearly define the attributions that correspond to the highest governing body (be it the General Assembly, the Governing Council, or the Board), and the functions that will be the responsibility of senior management. However, both functions must be complementary [54]. In the study case, its organizational chart reveals a classic organization of a hierarchical and functional type. Although the Governing Board makes the strategic decisions, the function of leading the organization is not exercised by its president; this responsibility is assumed by the general director. Moreover, it is the management team that is responsible for ensuring 
compliance with the strategic initiatives taken by the Governing Board, as well as the short-term operational objectives.

\subsubsection{The Values and the Code of Ethics}

The importance of the values and the code of ethics lies in the fact that, in addition to directing personnel and setting limits to behaviors that are considered ethical [55], the values must be based on the organization's actions towards the fulfilment of the vision [56]. The data of the study reveal the importance for the organization to transmit the values and the code of ethics to all staff, together with the vision and mission.

\subsubsection{The Vision, Mission, and Strategy}

These are elements that must be formulated involving the key personnel of the organization and must be communicated [11]. To facilitate the formulation of the strategy, the mission must be based on vision and values [55]. Also, the business model must also be designed, because this will be decisive [54] since the strategy must include how it is going to help achieve business objectives in a more effective and efficient way, through a competence-based organization. Given that the values, vision, and mission are defined in the case study, it can be said that the strategy is enunciated; although the analysis of the data indicates that it is not formulated. They did not shown evidence of the business model, nor the objectives and strategic plans; however, there is evidence that they carry out key strategic initiatives for the business, as this participant states:

No, man! but the strategy, I do not know exactly what you mean. We, right now, for example, is related to the change we have made to biodynamic agriculture. Perhaps what we have not done is to write why we are going to do biodynamic agriculture (Participant 1:131).

In this regard, we made an observation: without a clearly-defined strategy, with its respective objectives and plans, the organization cannot know whether the initiatives they undertake contribute to achieving the organization's mission and vision.

In order to become a project-based organization, IPMA OCB [11] suggests that the mission and vision should include the specific purpose, goals, and objectives of the management with respect to the PM, in addition to showing the strategy to achieve it. For such purposes, the standard specifies that the objectives and key performance indicators (KPIs) must be defined and, thus, facilitate the monitoring of the strategy evolution.

\subsubsection{Objectives for Performance and KPIs}

Based on the principle of Kaplan and Norton, which establishes that you cannot control what cannot be measured [57]; and as stated by IPMA OCB [11], that in a competitive environment, organizations use efforts to achieve goals in an effective and efficient way, mobilizing people and resources to materialize the mission, vision, and strategy; project-based organizations need to achieve the goals set for performance. These objectives must be disaggregated into goals and activities. Also, the KPIs, for their supervision and regular control, must be specific, measurable, acceptable, and realistic, in addition to being linked to a runtime. Although the responses of the participants in the study reveal that they do not recognize these terms, the evidence indicates that they formulate the objectives and KPIs for performance both at the general level and for each area of work in particular. They do this annually and conduct regular follow-ups.

To encourage compliance with performance objectives and influence the implementation of the strategy, Ayub et al. expressed that solid leadership must be provided, because it is a determinant of the motivation and performance of the personnel [58]. 


\subsubsection{Leadership}

In order to focus the efforts of a group towards a common goal, leadership manifests itself by clearly defining and communicating goals and expectations at all levels [11,59].

Two key elements can be derived from the concept: a common goal and communication. Of them, in the analyzed data, communication stands out as the main characteristic.

For a common objective, the analysis of the data confirms the importance of communication between management their team, to clearly and directly specific the goals of their respective areas in order to promote in the commitment to and achievement of the desired results. This is revealed by the following response:

Let's see! If A.G. tells me that I have to make 98 kilos, an example, per hour and per woman in the flow machine, if I know that and nobody else knows, no matter how much we do, they cannot [reach the goal] ... Then, what I have done now has been to take the person responsible for production and who is responsible for the line, and I said to him: "Hey, look, let's see, this is what ... take this and this is how we go; we go below, or we go above. Here you are doing well, here you have to squeeze a little more to the people. And so, we are going to see it, because otherwise, it's impossible ... I cannot achieve the goal alone (Participant 6:139).

Perhaps for this reason, communication has stood out as the critical aspect of leadership within the organization. Indeed, communication and leadership go hand in hand [60], since leadership provides an important context for the practice of internal communication [61], thus constituting an essential aspect of organizational changes [62]. The results support this, ensuring that the exchange occurs between the main sources at the internal level of the organization. This exchange is a fundamental aspect of leadership, as it guarantees communication at the vertical and horizontal levels $[63,64]$. In that sense, the analyzed data highlights:

- The importance of formal communication, referring to communication in which the message has a direct and clear direction [65], since frequent meetings of the Governing Board as well as between the general manager and his management team are essential to monitoring compliance with the objectives set, as well as to provide guidance to staff on topics of interest to the organization.

- The importance of top management being accessible, projecting an open, understanding attitude, and demonstrating that they listen and take into account the staff's opinions, because this transmits confidence, encouraging staff to be open communication. This was also reported by Hasell (2016), when he declared that trust is the main element that contributes to this type of communication [66]. This is expressed by the following participants:

... it helps us a lot and we can talk to him perfectly about everything (Participant 10:54). For example, these days I had an accident, I broke something here in the warehouse, and I had to talk to him. Man! he did not directly say anything to me, he did say: "Well, it's fixed and that's it." But I, because I was a bit worried, I went up to talk with him and I had no problem, nor was ... Well, he gave me some advice: "be careful" ... That's very good (Participant 10:56).

... if they have made decisions that maybe I have seen that it could be done differently, or put it in the best possible way, I have always given my opinion. And if it has been better, it is always taken into account (Participant 9:188).

- The positive assessment that managers make to the culture. They have to converse and seek solutions to problems that may affect interpersonal relationships. Also, due to the fact that there is no bureaucracy and that the communication between partners and managers is direct, because it makes it easier to solve problems quickly. Although, it was pointed out that this is possible because there are few members. 
- The need for the general manager not to neglect the day-to-day business and to maintain frequent communication with managers at the individual level, as well as to avoid the perception of ineffective communication, as indicated by the following:

I sometimes do a little missing, maybe more presence of the management... that is, at the time of day to day. Because there are things that, I do not know, it would be important to see them more continuously. And, maybe, the belief in your team... trust your team, enough; that is, totally. But of course, there are things that, or decisions, that you need to see with him... (Participant 5:154).

I do not think so. Totally effective, no ... perhaps what is missing, which is another thing I am starting to work on, is more communication between that manager and me [general manager], but individually (Participant 1:147).

- The need for the management team to be involved in the strategic decisions taken by the Governing Board. As Ethugala (2011) stated, for business decisions to be solid and relevant, they have to be transmitted to the entire organization [67]. In this regard, one participant considers that:

... decisions are often made unilaterally, without having a more global vision of how this decision can affect the entire business, especially in the daily work (Participant 2:136).

- The need for greater communication among people in different areas of work, in addition to knowing who they are and the role they play, as the evidenced by the following:

Well, what I said before, a little more communication and knowing exactly each one, a little more knowing what each one does; at least in the main positions. To know exactly, to know people better. First, to the person who is there, and then the work he does. And the management itself, which knows people very well, especially the people who are just at the next level (Participant 7:196).

The aforementioned aspects could serve as indicators for the organizational government to evaluate and reflect on the leadership style used internally. Based on this, the organization should take the measures that it deems appropriate to guarantee the most appropriate leadership.

\subsection{Dimension 2: Strategic Social Responsibility Initiatives}

As a way to contribute to minimizing the effects of agriculture on the environment and to ensure the safety of food, this study highlights actions for sustainable agriculture and the university-business link. On the one hand, given that the intensification and extensification of agriculture to feed the growing human population are responsible partly for today's global environmental problems [68], the current situation demands the management of a socially- and ethically-justified agriculture, that is economically viable and environmentally healthy [69]. In this sense, the results show that alliances between the organization and universities and research centers are fundamental to promote technological advances related to organic farming, since it is necessary to develop new sustainable strategies for the protection and improvement of crops that do not depend on harmful chemical substances [70].

In this aspect, the organization is committed to organic and biodynamic agriculture. In addition, with the objective of "... applying R\&D\&I in agriculture to replace chemical pesticides by biological methods" (Document 6:1:234), the organization "... is part of the Plant Response Biotech company, a 'Spin-off' from the Polytechnic University of Madrid, which develops new products and methods for the protection of crops against pathogens and pests, and investigates resistance to salinity and water stress conditions" (Document 1:786). They also have their “... own test fields and agreements with the Center for Plant Biotechnology and Genomics ... of the Polytechnic University of Madrid, which carries out the investigations on demand of Camposeven" (Document 6:1:916). Likewise, within the 
framework of the Ingenio Foundation, which is chaired by the CEO of the ATS Camposeven, they have signed an agreement to offer internships to final-year students and support young people to join the professional world (Document 3:2:1050).

\subsection{Dimension 3: Values in Interpersonal Relationships}

In the integration of approaches that prioritize people, the study also highlights the values that underlie interpersonal relationships, which contribute to social cohesion within the organization and give rise to a favorable environment for work. These are: trust and a sense of belonging and commitment. Trust, which is one of the values pursued in a project-based organization [71], arises from the bond of friendship created over time, a result supported by Hasell (2016) when he declared that, on the basis of these relationships, confident and highly-committed members were developed [66]. For example, among associates, one of them declared: "Precisely, we all have a relationship ... as very close. As very, I do not know, I was going to say brotherhood" (Participant 11:24). For his part, a participant, with respect to the general director, says: "That all that, there is a lot of communication ... As we are so well known and friends, and we have been here a lot, there is a lot of friendship and he trusts in us and, he is open! I do not know how to explain to you ... That this is a family here, and we always communicate." (Participant 10:74). In that sense, the confidence that the general director transmits to his work team translates, fundamentally, into the capacity of the people to express themselves openly on any subject.

In a project-based organization, all management levels must demonstrate their commitment to achieve their vision, mission, and strategy, through effective communication with all parties and proactive involvement [11]. The study data show that the sense of belonging and the commitment of the people working in the organization have an important impact on the trust of the members. For example, the study of Global Trends in Employee Commitment 2015, conducted by Aon Hewitt [72], revealed that there is a consistent and statistically significant relationship between a high level of staff commitment and the financial performance of the organization. In effect, the analyzed data indicated that the high level of belonging and commitment shown by managers and middle managers is a determining factor in the trust that members place in these people and in the management of the organization in general. The following explanation is given by one of the partners:

I, to the commercial department, I already told you, at least the guy in there, I have a lot of confidence in him. Because, what is it that we have searched for since we left the other cooperative? To have our own commercial department. But apart from that, then having someone you trust ... Because it is that, commercially, it is very easy to waste a lot of money ... and you do not find out (Participant 11:72).

I know that he gives everything for working, he does not give up the product, as I told you. He fights and defends it. And I know that, in the warehouse, the same is done; the one who buys the cardboard, does the same; with the workforce ... I mean, with everything. There are a lot of people who in the end, are defending all this. That money that finally remains, is what we earn (Participant 11:78).

In this study, it is suggested that the governance of the organization should take into consideration which elements influence the construction of trust relationships and, based on this, define the most appropriate initiatives to foster this type of relationship among its members, as well as organize activities to promote a sense of belonging in them and put into practice actions that contribute to increasing and/or maintaining their level of commitment at work.

\subsection{Dimension 4: Actions that Generate Social Learning}

In addition to the values highlighted in interpersonal relationships, the study also highlights the actions that lead to learning from collective action, which, likewise, contribute to social cohesion within 
the organization. The results indicate that the organization produces actions that create favorable scenarios for the generation of social learning between partners; that is, for the integration of knowledge and the action that they themselves experience [13]. These actions have to do with the exchange of information, experiences, and mutual help.

Paauwe (2004) points out that the relationship of exchange between the organization and its personnel is important, and that not only does it involve work, money, and time, it must also encompass knowledge, competences, information, participation, and well-being [73]. The analysis of the data highlights the learning generated by the members from the collective action, by spontaneously exchanging information about the experiences lived on their own farms, helping each other, and thus strengthening the process. The important thing is that this collective action, taking the definition of Ostrom (2015), arises voluntarily for the intention of the group to benefit from the shared interest to achieve a common goal [74]. The truth is that mutual aid is one of the basic values of cooperative social morality, and in a highly-competitive context, this constitutes the most valuable resource to overcome the strongest [75]. For this dimension, the results suggest that the trust that exists between the members influences such an exchange and helps it to occur; this was explained by Pretty and Ward (2001) when they declared that reciprocity and exchange are a direct consequence of trust because of the existence of social ties, which are a basic requirement of cooperative relations [76].

\subsection{Dimension 5: Strategic Initiatives of a Technical-Business Nature}

In the interest of contributing to the sustainability of the AS, in addition to the initiatives of a social nature, and in spite of the need to overcome the merely technical aspects, it is unquestionable that the initiatives of a technical-business nature constitute an irreplaceable element of the strategy of any organization. In this aspect, the study highlights the commitment to innovation and technology and the need to establish a quality management system.

Innovation is essential for the survival of organizations [77], and, in the case of agri-food, their performance depends, to a large extent, on the effective application of existing technologies that improve productivity [2,3]. In fact, Galanakis (2016) considers that, in order to face new challenges and comply with the responsibilities of food safety and respect for the environment, innovation should be perceived not only as an opportunity, but also as a precondition for success, since it is identified as a basic requirement to ensure the sustainability and competitiveness of the sector [5]. In that sense, according to the data analyzed, the key strategy of the business has been to innovate in the production processes, for example by changing from conventional farming to organic and biodynamic farming. The reason for this is that, in a highly-competitive market, where the sensitivity of consumers for social responsibility and environmental sustainability is increasing [2], initiatives focused on contributing to people's health and respect for the environment differentiate an organization from its competitors. In this regard, on the introduction of innovations, the data suggest that the "innovative spirit" of the members was decisive. This is evidenced by the views of the following participant:

Well, look at this. These farmers, when they started (in short, they are farmers with more than 40 years of experience), started with the traditional crops that were made here in the area, and were the first farmers who began to make a totally different type of greenhouse structure, as it is now the structure they have in the Netherlands, multi-tunnel greenhouses. And they also started with the hydroponic farming and the management of their farms through computers (Participant 1:37).

It shows a total and absolute innovation. Afterwards, they have been very innovative in varieties of the products that they cultivated. Doing tests with varieties that were not yet in the market. They made a field test where they were previously located and now here we have another field test. And then, they have been innovators in, well, moving from a conventional product culture, to that of a farmer in 20 or 30 years, since it is normal that he 
can evolve towards ecological farming, but it is not so normal that a farmer of 65 or 70 years spent living all his life cultivating a conventional product to go green (Participant 1:39).

Another important aspect is diversification, in relation to the introduction and development of new products, as well as the interest to try new forms of commercialization. The objective is to be able to cope with the crises and opportunities that arise in a world of constant change, in which, as explained by Hall (2007), a continuous process of innovation based on diversity is necessary [1]. The results also reveal that using technology to innovate in management methods is essential, since they not only facilitate manual tasks, but also provide instant information and facilitate decision-making [78], an aspect that highlights the usefulness of technology in management.

Regarding quality management, an organization must take into account the definition of ISO 9000:2005 which states that quality management is the set of coordinated activities to direct and control an organization in relation to the requirements for quality, which includes the establishment and application of the quality policy, its objectives and responsibilities, and which is carried out through quality planning, control, assurance, and continuous improvement [79]. This should be a strategic decision, adopted from a quality management system [80]. The result of the analysis suggests that the organization is based on strictly agri-food criteria, focused only on the quality of the product and the adoption of certifications as a key resource. One participant thinks about it: "No, it's not enough. Because they are focused on the quality of the product, let's say, but the quality of the process is a little more abandoned" (Participant 8:132). They also make reference to the fact that machinery is not regularly maintained, "... it was broken and fixed" (Participant 8:345); and the existence of outdated manuals for quality, with procedures that are so demanding that perhaps they are not available to the corresponding personnel. About this, he comments:

No, here, there is very little protocol, written on paper, very little. There is very, very, very little. Almost everything is improvised (Participant 8:50). There is a lot of writing, but it's there in the book, and down here [in the plant area] it is not explained (Participant 8:134) ... it is not used. Nor have we updated it ... (Participant 8:364) ... the thing is our internal quality controls have made them so demanding that we cannot meet them (Participant 8:390). So, let's try to make a more reasonable booklet! (Participant 8:392).

The results presented show the absence of a quality management system. Given that, in order to maintain socially responsible decision-making, it is not enough to prevent errors in products and services [81], we suggest evaluating to what extent the quality criteria are applied and reflecting on the most appropriate level, taking into account the needs of the business and the competitive environment in which it operates. This includes determining if it is sufficient to only focus on the quality of the product, or if applying quality criteria to the management of resources and management in general can represent an added value for the organization.

\subsection{Dimension 6: Practice and Development of PM}

To increase the chances of successfully carrying out any type of initiative through projects, the first thing is to be clear about its definition. A project is an operation with time and cost restrictions that aims to materialize a set of defined deliverables, in accordance with quality requirements and standards [11,82]. For its part, PM is the application of knowledge, skills, tools, and techniques to ensure that project activities meet the requirements of the project [52], which implies a standard life cycle to obtain beneficial changes, through the integration of processes, in which persons and financial and material resources are organized in a novel way $[59,82,83]$.

The results of the analyzed data indicate that, in the organization, the projects are confused with the operations and with any type of initiative that is executed with the best intention to reach the desired objectives. However, they have various initiatives that could be projects, some even with a certain degree of complexity, such as the conversion of conventional to ecological agriculture, and then 
to biodynamics; although they are not handled professionally as such. In fact, at present, they invest efforts and resources in an initiative that they consider to have managed as a project, but that "is not working" and they do not know the reason. This is declared by the following participant:

Well look, one of the things that does not work, and I would like to work, and I'm spending effort on it is, for example: we created a company (more than a company, now a business) within the same company... of Camposeven. So, this is for the online sale of organic products in Spain. That does not work well. There is no culture in Spain of, first, the online purchase of food products, vegetables and fruits (1:47). Well, the business started well, but that type of product has not been in great demand ... not to the expectations that I made for myself. Either the expectations we made were wrong, or something is not working well. That is the situation (Participant 1:53).

... There is a document of the beginnings of that project. There is an economic, financial, marketing study. Yes, yes, there is a project (Participant 1:55).

These results show that in the organization they do not know enough, nor apply any standard in PM; consequently, they do not know how to project their ideas. The practice and development of the PM involves taking into account some elements: in addition to the definition of projects and PM, one must know what a program is and what a portfolio is; know how they differ from operations and other activities; establish different categories of projects; use standards for PM; manage the information and documentation of the projects; and finally record and apply the lessons learned. To develop PM, the literature suggests to:

- Clearly define the objectives to develop the OCPM.

- Consider the use of a specific PM standard. Regardless of the choice of governing by projects as the appropriate form for general work, or the occasional use of PM for only some areas [84], the certification bodies and the academic and professional literature indicate that organizations that want to have success in PM must meet certain standards and practices [85].

- Consider making such standards an integral part of the organization's management system. This includes establishing relevant procedures to adapt the chosen standard to the specific needs of the organization and each PPP, as well as making the procedures accessible to all people involved, who must be familiar and properly trained in their use [11].

The success of projects depends fundamentally on the proper use of PM methodologies and specific tools [86,87]. In this sense, we reflect that without an adequate formulation of the initiatives that are executed, without analyzing and documenting the risks and opportunities that their realization entails, and without an adequate alignment of these initiatives with the global strategy of the organization, how is it possible to identify where the fault is when "something is not working well", to learn from mistakes, and avoid repeating them in the future? Additionally, how is it possible to identify the contributions of the actions they undertake to materialize the mission, vision, and strategy?

To enable the proper development of PM and motivate the use of specific methodologies and tools, especially at the beginning, when the road to projectification begins, it is necessary to manage the individual competences of the people and the corresponding roles of those that, in the near future, will be project managers.

\subsection{Dimension 7: Management of People's Competences}

As the projects are carried out by individuals, IPMA OCB [11] considers that, in order to fulfil the mission, vision, and strategy, a project-based organization must have the appropriate personnel and with the appropriate competences. To do this, the management of people's competences must be planned, a process for which the referred standard proposes three stages: 


\subsubsection{Defining the Competence Requirements of Individuals for Each Job Position}

The first step should be to define the functions for each job position and, on that basis, establish the competence requirements that directors, team members, and other personnel of the organization must meet. Competence, the level of knowledge, the associated skills and abilities, and whether or not experience is required for the position [11] as well as the requirements for each of these aspects must be included in the description. At this stage, authority limits should also be established and, when dealing with family organizations, succession plans should be formulated. In the case of agri-food organizations, whose owners run family farms, their respective succession plans should be defined. Drucker (2010) points out that this is a particularly relevant issue in this type of organization, due to the interests related to family ties and the need to safeguard the security and harmony of family members [88]. In addition, in the case of farmers, it is necessary to guarantee generational change, a need that is particularly important in the field of agriculture, due to the challenge it represents.

On these aspects, the results reveal that, in the organization, the competence requirements for each job position were not established-only the functions are described. No written evidence was found to define authority limits, although the data suggest that people are clear about them. There was also no evidence that the succession for each of the farms is planned, but the analysis shows that generational change is taking place among farmers who retire, as shown in the following quote:

... to be honest we are not many, anyway, some have already retired, but their children are following the agricultural tradition. There is a young environment within our group of members, and that is what makes us keep going (Participant 1:35).

\subsubsection{Evaluating the Current Status of the Competences of the People Who Work in the Organization}

The second step suggested by IPMA OCB [11] is the periodic evaluation of the competence of the staff, based on the previously-defined requirements for the functions of the jobs they occupy. The purpose is to analyze to what extent they are met. To this end, adequate procedures and tools for evaluation must be established, which may include professional certification, since it implies subsequent analysis and the evolution of the gaps detected. The result of the evaluation should be used to plan the appropriate actions to take advantage of the demonstrated strengths, to address any gaps, and to acquire those competences in which weaknesses have been detected, with the intention of fulfilling the expectations and requirements of established competences.

In this case, the managers indicate that they evaluate the competences of their team "by observation, by attitude, by many things. For interest ... " (Participant 3:206). However, based on which criteria are evaluated, what if the requirements for each position have not been defined? These answers, in addition to confirming that they do not have tools to assess the competence level, also suggest that they evaluate their staff by intuition, based on the competences that each manager experimentally establishes as necessary. The reflection that arises is, whether this is the most appropriate way to determine what competences need to be developed, or what new personnel, with what competences, they need to hire. If they do not know what the level of competence of the people is, how is it possible to define the plans for their development and professional improvement?

\subsubsection{Establishing Procedures to Acquire the Competences Required for Each Position}

Once the weaknesses that must be resolved are identified, planning the most appropriate actions involves determining which competences will be developed and which will be improved through practice or training, as well as which competences should be acquired by hiring new people. Whether you choose to encourage the development and improvement of the competences of the staff that the organization already has, or if someone is going to be hired, the procedures should be established and the appropriate tools for each process should be provided. In the case of hiring, based on the competences defined for each job, it is necessary to define procedures and tools, to identify, evaluate, and select potential candidates, enabling the selection of new hires from within the staff 
(to promote positions, for example), or from external sources available (temporary employment agencies, employment agencies, etc.) [11].

In the organization, when evaluating people by simple observation, it indicates that each manager experimentally determines which competences should be developed and when it is necessary to hire someone. Some managers are responsible for hiring their own staff, some are selected from internal staff, from people who occupy other positions, and others look for new hires externally. While the general director is in charge of the personnel related to the administrative staff, in all cases, the process is carried out without defined criteria or adequate tools. For example, on the hiring of workers in the plant area, who use the services of a temporary work agency, one of the participants expresses:

... the interview, the truth is that it is very basic ... it is totally intuitive ... (Participant 8:32).

... yes, it is intuition, but we would have to make a small model for candidate interviews, a small folio where you say: let's see, things that I have to ask you, basic things that maybe are not in your curriculum (Participant 8:38).

In that sense, if there is no defined criteria or adequate tools to assess the competences of the candidates in the personnel selection process, what is the guarantee that the most suitable personnel are being hired for the job to which they apply?

On the other hand, the results of the study highlight the importance for the organization to promote the development and continuous improvement of the professional skills of its staff, with the intention of taking advantage of their capabilities as the first alternative to hiring. As the CEO declares:

Because of my philosophy, and what I want to promote here, is that we make the most of the resources we have within the company, so that, when you have to promote or look for a person for a position of more responsibility, look first within the people that you have inside the company, so to speak. And then, make a career plan for them (Participant 1:113).

In this case, IPMA OCB [11] suggests that, in order to encourage the development and continuous improvement of the competences of the personnel available, in order to comply with the requirements defined for the position, the appropriate methods and providers must be selected. For example, this development may include training (whether at work or outside of it) and preparation for the acquisition of certifications, etc., which may involve the use of services of external providers, or be provided internally. They should also establish procedures and tools to evaluate the results of development activities, which should be documented. In this sense, the analyzed data indicate that training occupies an important place for the organization. For example, in addition to providing managers with regular training on leadership and motivation, they also facilitate the specific training that each one requires for the best performance of their position. This is shown by the evidence:

So far, in the training we have done, there was a bit of everything. We are doing joint training in the management team and then each one ... I, for example ... because of my position, I am very interested in English and all that ... I have been doing English courses, the company has paid a part of it. To the other lady that we have as an assistant, I saw a course that was interesting and I told her: "Hey, this may interest you". We talked about it between the three of us and then she said yes and she did it, and so, a little ... (Participant 7:136).

However, they do not evaluate or document the results of development activities. Thus, in what way can they know if the resources invested in these activities have improved performance?

Planning and carrying out these steps requires organized human resources management (HRM) [89], which is aligned with the context and organizational strategy [83]. In the case of projects, the function of managing people's competences must be assumed by project managers, as well as supported by HRM and other managers [11]. However, in the organization, there is no human resources department and the data reveal that people's competences are not managed. On this aspect, Huemann 
(2010) pointed out that even organizations oriented to relatively mature projects still struggle with inadequate HRM. Still, the importance of HRM must be emphasized for the transformation towards a project-oriented organization, offering appropriate training in PM [89].

The need for a correctly-formulated strategy, the absence of a quality management system, the confusion between projects and operations, and with it the lack of knowledge on how to project their ideas and how projects fit into the agri-food business, as well as the absence of organized HRM and the need to manage people's competences all suggest the need to change the management approach and to evolve towards new forms of governance that allow the organization to adapt to current conditions in order to maintain a more competitive and sustainable position in the market. In this sense, after gaining a general vision of where the organization is currently, we invite them to reflect on where they want to go, whether they consider that the current management form is sufficient for business expectations and to face the challenges that arise, or if they are willing to implement new management techniques. Based on this, they must define their strategy.

\section{Conclusions}

Today's global environmental and social problems represent, for organizations and farmers in the agri-food sector, challenges as well as opportunities for diversification and added value, generating the need for important projects and new forms of governance. The demand for a sustainable AS requires that the sector organizations integrate initiatives that contribute to achieving this, including governance systems that allow them to adapt and remain in a market that is constantly changing and increasingly competitive, looking for the balance between the economic, social, and ecological dimensions of sustainability.

The theoretical referents of the study and the result of the analyzed data led us to consider that project-based governance can help, for this agri-food cooperative in particular, to define a governance model that allows them to face the challenges of the current context, extracting competitive advantages through PPP to achieve the strategic objectives of the organization. The results obtained by implementing the plan in this cooperative may potentially be applicable to other cooperatives in the sector. To the extent that project-based governance helps agri-food organizations to face the challenges of the current context, it also contributes to the sustainability of the AS, since it enables these organizations to defend their position in the market and to be sustainable. This is because the efficiency and effectiveness of this type of organization depend on its capacity to face the changes that arise in the sector and the challenges of the future, and its proper functioning is necessary for the competitiveness of the AS, not only the Spanish AS [90] but global agri-food systems as well.

If the decision is made to move towards the implementation of a project-based governance system, after reviewing the mission and vision and based on the decision of where the organization wants to go, it is essential that they clearly define the strategy, including the specific objectives for the development of the PM. In this phase, it is recommended to formulate the internal project that will guide the projectification process, with a development focus from lower to higher levels of competence. That is to say, it starts with the planning of the development of the individual competences, going through the development and the continuous improvement of the organizational competences, until reaching the highest level of maturity desired; with the purpose, as suggested by Kwak et al. (2015), of identifying the interconnection between improvement efforts and results [91].

In order to adequately manage the PM competences of the key personnel for the organization's projectification process, the following are recommended:

- Organize the HRM. Taking HRM into account, to add value to the business, some authors have emphasized that this must be aligned with the context and strategy of the organization [73,92].

- Identify potential project managers, in order to provide them with standardized training to develop the careers of PMs. The competences in this field increase the potential for the transformation of the organization, which is important in the face of the changes that the HRM 
will have to undertake, related to linking the new processes of the projects with the own processes of the HRM [89].

- Provide specific training for any other function. The analyzed data reveal that a key resource to develop the human talent that the organization needs is training, which allows the continuous improvement of the professional competences of personnel, in such a way that their capacities are exploited while promoting the development of competence requirements that are not yet met.

Organizing the HRM, the management of people's competences, and having provided future project managers with the specific related training, it is necessary to apply the acquired knowledge to learn on the fly and gain skills, while contributing to the process of the organization projectification, by integrating the role of projects in processes in the organizational structure and in the culture of the people. To the extent that people learn from themselves and with others during the process, the acquisition of necessary skills should improve skills all around and evolve the workforce to reach the required level of competence.

Both to organize the HRM process based on projects and the personnel competence management process, as well to implement the organizational alignment at a later stage and to serve as a guide during the process of projectification, a practical option could be the hiring of a group of expert people, or at least of one person, who, according to Wagner (2017), could be a CPO (Chief Programme Officer), in which case he must have the appropriate competences for the PPP management. Still, according to the author, it is more important for the candidate to have experience and a solid network of professionals for a better performance of the aforementioned responsibilities. The role of a CPO should also be aligned within the other roles of the Board of Directors [93].

Whatever the case, at the end of the process of the organization projectification, the figure selected for the above purposes (a CPO or a group of expert people) could also continue to support the PM system, while ensuring the continued development of the OCPM. The intention is for these actions to be seen as a rational effort to implement new management techniques, management skills, and competences, as well as to shape the organization [94]. In this sense, we consider key personnel committed with the transformation process, and that social learning will play a significant role, since it will be necessary to work as a team, exchanging information and experiences, learning by doing, and helping each other. This will lead to joint learning.

Through the case study presented, we attempted to discover what strategies and ideals make a small organic agri-food cooperative successful and contribute to its own sustainability, as well as the sustainability of its community. The results indicated that to move towards sustainability from the cooperative strategy to the strategy of working by projects, multiple forms and approaches can be sequenced and combined.

Throughout the 40 years of experience in managing these types of agri-food cooperatives, the right approach of the WWP, as a conceptual proposal to address project-based governance from three dimensions (political-contextual, technical-business, and ethical-social) was demonstrated. It extends much further than simply the "technical" aspects of the projects and emphasizes the behavior of individuals and the contexts in which the team work. In our case, from its dimensions, at the core of the WWP approach, the balance between the three sustainability dimensions (environmental, economic and social) is necessary. The elements that farmers believe conform their sustainability are in accordance with the multidimensionality concept of sustainability. The elements that they highlighted can be considered as the goals they want to reach for the implementation of a project-based governance system, through the different dimensions identified. We found that stakeholders and project managers should also use a social integration approach for "working with people" in order to provide a balance between the three elements of sustainability.

Author Contributions: A.T.H.-R. designed the research, collected and analyzed the data, developed the framework, and wrote the document; I.D.L.R.C. reviewed the manuscript, provided methodological and professional guidance in the field of WWP, and helped to edit the document; J.M.-A. provided professional 
and continuous guidance in the field of OCPM and IPMA OCB and helped in the interpretation of related data. All authors reviewed and approved the final document.

Funding: The authors received no financial support for the research.

Acknowledgments: We are grateful to have complemented this study with data from the European research project Rethink. We would also like to thank the AST Camposeven for their very kind collaboration.

Conflicts of Interest: The authors declare no conflict of interest.

\section{References}

1. Hall, A. Challenges to Strengthening Agricultural Innovation Systems: Where Do We Go From Here? Working Paper Series; UNU-MERIT: Maastricht, The Netherlands, 2007; Volume 38.

2. Dennis, C.; Aguilera, J.M.; Satin, M. Tecnologías que dan forma al futuro. In Agroindustrias Para el Desarrollo; FAO, Ed.; FAO: Roma, Italy, 2013; pp. 103-147.

3. Da Silva, C.A.; Baker, D. Introducción. In Agroindustrias Para el Desarrollo; FAO, Ed.; FAO: Roma, Italy, 2013; pp. 1-10. ISBN 9789253074136.

4. Hubeau, M.; Marchand, F.; Van Huylenbroeck, G. Sustainability experiments in the agri-food system: Uncovering the factors of new governance and collaboration success. Sustainability 2017, 9, 1027. [CrossRef]

5. Galanakis, C.M. Challenges and Opportunities. In Innovation Strategies in the Food Industry: Tools for Implementation; Elsevier: New York, NY, USA, 2016; pp. 293-304.

6. Lachman, D.A. A survey and review of approaches to study transitions. Energy Policy 2013, 58, $269-276$. [CrossRef]

7. Meynard, J.-M.; Jeuffroy, M.-H.; Le Bail, M.; Lefèvre, A.; Magrini, M.-B.; Michon, C. Designing coupled innovations for the sustainability transition of agrifood systems. Agric. Syst. 2017, 157, 330-339. [CrossRef]

8. Pettigrew, A.M. Innovative forms of organizing: Progress, performance, and process. In Innovative Forms of Organizing: International Perspectives; Pettigrew, A.M., Whittington, R., Melin, L., Sanchez-Runde, C., Van den Bosch, F.A.J., Ruigrok, W., Numagami, T., Eds.; SAGE Publications Ltd.: London, UK, 2003; pp. 331-351. ISBN 9780761964360.

9. Jamieson, A.; Morris, P.W.G. Moving from corporate strategy. In The Wiley Guide to Managing Projects; Pinto, J.K., Morris, P., Eds.; John Wiley \& Sons: Hoboken, NJ, USA, 2004; pp. 177-205. ISBN 9780471233022.

10. Wagner, R.F. Organisational competence in project management-New perspectives on assessing and developing organisations. J. Proj. Progr. Portf. Manag. 2012, 3, 45-57.

11. IPMA OCB. Organisational Competence Baseline for Developing Competence in Managing by Projects; International Project Management Association: Amsterdam, The Netherlands, 2016; ISBN 978-84-616-8576-9.

12. Maylor, H.; Brady, T.; Cooke-Davies, T.; Hodgson, D. From projectification to programmification. Int. J. Proj. Manag. 2006, 24, 663-674. [CrossRef]

13. Cazorla, A.; De Los Ríos, I.; Salvo, M. Working with People (WWP) in rural development projects: A proposal from social learning. Cuad. Desarro. Rural 2013, 10, 131-157.

14. De los Ríos, I.; Díaz-Puente, J.M.; Cadena-Iñiguez, J. The initiative LEADER as a model for rural development: Implementation to some territories of México. Agrociencia 2011, 45, 609-624.

15. De los Ríos, I.; Guillén, J.; Herrera-Reyes, A.T. Complexity in the Management of Rural Development Projects: Case of LASESA (Spain). Cuad. Desarro. Rural 2013, 10, 167-186.

16. De los Ríos, I.; Ortuño, M.; Rivera, M. Private-public partnership as a tool to promote entrepreneurship for sustainable development: WWP torrearte experience. Sustainability 2016, 8, 199. [CrossRef]

17. Herrera-Reyes, A.T.; Rivera, M.; De los Ríos, I. Social Learning in Innovation for Resilience of a Territory Through University-company Links. Procedia Soc. Behav. Sci. 2015, 191, 2117-2121. [CrossRef]

18. Stratta, R.; De los Ríos, I.; González, M. Developing Competencies for Rural Development Project Management through Local Action Groups: The Punta Indio (Argentina) Experience. In International Development; Appiah-Opoku, S., Ed.; InTech: Rijeka, Croatia, 2017; pp. 153-172.

19. Ávila, C.; De los Ríos, I.; Martín, S. Illicit crops substitution and rural prosperity in armed conflict areas: A conceptual proposal based on the Working with People model in Colombia. Land Use Policy 2018, 72, 201-214. 
20. Winch, G. Rethinking project management: Project organizations as information processing systems? In Proceedings of the PMI Research Conference, London, UK, 11-14 July 2004; Project Management Institute: London, UK, 2004.

21. Cicmil, S.; Marshall, D. Insights into collaboration at project level: Complexity, social interaction and procurement mechanisms. Build. Res. Inf. 2005, 33, 523-535. [CrossRef]

22. Cooke-Davies, T. De-engineering project management. In Proceedings of the International Research Network on Managing by Projects. Biannual Conference, Turku, Finland, 25-27 August 2004.

23. De Los Ríos, I.; Cazorla, A.; Díaz-Puente, J.M.; Yagüe, J.L. Project-based learning in engineering higher education: Two decades of teaching competences in real environments. Procedia Soc. Behav. Sci. 2010, 2 , 1368-1378. [CrossRef]

24. Davies, A.; Hobday, M. The Business of Projects: Managing Innovation in Complex Products and Systems; Cambridge University Press: Cambridge, UK, 2005; ISBN 9781139447843.

25. Morris, P.W.G.; Pinto, J. The Wiley Guide to Managing Projects; John Wiley \& Sons: Hoboken, NJ, USA, 2004; ISBN 97804712233022.

26. Flyvbjerg, B.; Holm, M.S.; Buhl, S. Underestimating costs in public works projects. Error or lie? J. Am. Plan. Assoc. 2002, 68, 279-295. [CrossRef]

27. Sastre-Merino, S.; Negrillo, X.; Hernández-Castellano, D. Sustainability of Rural Development Projects within the Working with People Model: Application to Aymara Women Communities in the Puno Region, Peru. Cuad. Desarro. Rural 2013, 10, 219-244.

28. Hannouf, M.; Assefa, G. Life Cycle Sustainability Assessment for Sustainability Improvements: A Case Study of High-Density Polyethylene Production in Alberta, Canada. Sustainability 2017, 9, 2332. [CrossRef]

29. Hermans, F. Social Learning in Innovation Networks: How Multisectoral Collaborations Shape Discourses of Sustainable Agriculture. Ph.D. Thesis, Wageningen University, Wageningen, The Netherlands, 2011.

30. Jahn, T.; Bergmann, M.; Keil, F. Transdisciplinarity: Between mainstreaming and marginalization. Ecol. Econ. 2012, 79, 1-10. [CrossRef]

31. Comisión Europea. El Futuro de los Alimentos y de la Agricultura. Comunicación de la Comision al Parlamento Europeo, al Consejo, al Comité Económico y Social Europeo y al Comité de las Regiones; Comisión Europea: Bruselas, Belgium, 2017.

32. Hubeau, M.; Marchand, F.; Coteur, I.; Mondelaers, K.; Debruyne, L.; Van Huylenbroeck, G. A new agri-food systems sustainability approach to identify shared transformation pathways towards sustainability. Ecol. Econ. 2017, 131, 52-63. [CrossRef]

33. Ramanathan, U.; Gunasekaran, A. Supply chain collaboration: Impact of success in long-term partnerships. Int. J. Prod. Econ. 2014, 147, 252-259. [CrossRef]

34. Curry, N.; Kirwan, J. The Role of Tacit Knowledge in Developing Networks for Sustainable Agriculture. Sociol. Rural. 2014, 54, 341-361. [CrossRef]

35. Ikerd, J.E. The need for a system approach to sustainable agriculture. Agric. Ecosyst. Environ. 1993, 46, 147-160. [CrossRef]

36. Pretty, J.N. Participatory learning for sustainable agriculture. World Dev. 1995, 23, 1247-1263. [CrossRef]

37. Knickel, K.; Brunori, G.; Rand, S.; Proost, J. Towards a Better Conceptual Framework for Innovation Processes in Agriculture and Rural Development: From Linear Models to Systemic Approaches. J. Agric. Educ. Ext. 2009, 15, 131-146. [CrossRef]

38. Moschitz, H.; Roep, D.; Brunori, G.; Tisenkopfs, T. Learning and Innovation Networks for Sustainable Agriculture: Processes of Co-evolution, Joint Reflection and Facilitation. J. Agric. Educ. Ext. 2015, 21, 1-11. [CrossRef]

39. Šūmane, S.; Kunda, I.; Knickel, K.; Strauss, A.; Tisenkopfs, T.; De los Ríos, I. Local and farmers' knowledge matters! How integrating informal and formal knowledge enhances sustainable and resilient agriculture. J. Rural Stud. 2018, 59, 232-241. [CrossRef]

40. De los Ríos, I.; Rivera, M.; García, C. Redefining rural prosperity through social learning in the cooperative sector: 25 years of experience from organic agriculture in Spain. Land Use Policy 2016, 54, 85-94. [CrossRef]

41. Darnhofer, I.; de los Ríos, I.; Knickel, K.; Koopmans, M.; Lamine, C.; Almered, G.; Tisenkopfs, T. Rethinking the Links between Farm Modernisation, Rural Development and Resilience in a World of Increasing Demands and Finite Resources; Ruragri ERA-NET: Ghent, Belgium, 2014. 
42. Becerril, H.; De los Ríos, I. Energy Efficiency Strategies for Ecological Greenhouses: Experiences from Murcia (Spain). Energies 2016, 9, 866. [CrossRef]

43. Vargas, C. Estudios Agrarios; Procuraduría Agraria: Ciudad de México, México, 2009; pp. 75-108.

44. CARM Diferencias Con Otras Sociedades. Available online: https://www.carm.es/web/pagina? IDCONTENIDO=1903\&IDTIPO=11\&RASTRO=c80\$m22721,22746,2421,2422 (accessed on 22 November 2016).

45. Escuela de Organización Industrial (EOI). Las Sociedades Agrarias de Transformación como Entidades Generadoras de Empleo, Desarrollo Rural y Economía Social; EOI: Madrid, Spain, 2004.

46. Bel, P. Similitudes y diferencias entre las Sociedades Cooperativas Agrarias y las Sociedades Agrarias de Transformación a la luz de los principios cooperativos tras el Congreso de Manchester. REVESCO Rev. Estud. Coop. 1995, 61, 107-125.

47. De los Ríos, I.; García, C.; Herrera-Reyes, A.T.; Rivera, M. Innovation and Social Learning in Organic Vegetable Production in the Region of Murcia (Spain); Ruragri ERA-NET: Ghent, Belgium, 2015.

48. BMJ. Nuremberg Code (1947). BMJ 1996, 313, 1448. [CrossRef]

49. Strauss, A.L. Qualitative Analysis for Social Scientists; Cambridge University Press: Cambridge, UK, 1987; ISBN 9780521338066.

50. Rubio, M.J.; Varas, J. El Análisis de la Realidad en la Intervención Social: Métodos y Técnicas de Investigación, 3rd ed.; Volumen 9 de Campus; CCS: Madrid, Spain, 2004; ISBN 9788483168516.

51. Casasempere, A. Curso Avanzado de Análisis de Datos Cualitativos con ATLAS.ti; CualSoft: Alcoy, España, 2012.

52. González, T.; Cano, A. Introducción al análisis de datos en investigación cualitativa: Tipos de análisis y proceso de codificación. Parte II. Nure Investig. 2010, 45, 10.

53. Saldaña, J. The Coding Manual for Qualitative Researchers; SAGE Publications Inc.: Thousand Oaks, CA, USA, 2015; ISBN 9781473943582.

54. Baamonde, E. El cooperativismo agroalimentario en España: Pasado, presente y futuro. In El Papel del Cooperativismo Agroalimentario en la Economía Mundial; Mediterráneo Económico; Cajamar Caja Rural: Almería, Spain, 2013; pp. 191-204.

55. Bohlander, G.W.; Snell, S. Managing Human Resources; Cengage Learning: Mason, OH, USA, 2010; ISBN 9780324593310.

56. Sidhu, J. Mission statements: Is it time to shelve them? Eur. Manag. J. 2003, 21, 439-446. [CrossRef]

57. Kaplan, R.S.; Norton, D.P. The Balanced Scorecard: Measures that Drive Performance. Harv. Bus. Rev. 1992, 1, 71-79.

58. Ayub, S.H.; Manaf, N.A.; Hamzah, M.R. Leadership: Communicating Strategically in the 21st Century. Procedia Soc. Behav. Sci. 2014, 155, 502-506. [CrossRef]

59. PMI. A Guide to the Project Management Body of Knowledge-PMBOK®Guide, 5th ed.; Project Management Institute: Pennsylvania, PA, USA, 2013; ISBN 9781935589679.

60. Campbell, G.M. Idiot's Guides: Project Management, 6th ed.; Penguin Group: New York, NY, USA, 2014; ISBN 9781615645336.

61. Men, L.R. The internal communication role of the chief executive officer: Communication channels, style, and effectiveness. Public Relat. Rev. 2015, 41, 461-471. [CrossRef]

62. Mitrofan, N.; Bulborea, A. The Role of Organizational Communication in Structuring Interpersonal Relationships. Procedia Soc. Behav. Sci. 2013, 76, 511-515. [CrossRef]

63. Ivancevich, J.M.; Matteson, M.T. Organizational Behavior and Management, 6th ed.; McGraw-Hill: Boston, MA, USA, 2002; ISBN 9780072436389.

64. Jaradat, Y.M.; Sy, M.V.U. Organizational communication practices of Toc Glycol company Ltd., Thailand. Procedia Soc. Behav. Sci. 2012, 40, 122-127. [CrossRef]

65. Král, P.; Králová, V. Approaches to changing organizational structure: The effect of drivers and communication. J. Bus. Res. 2016, 69, 5169-5174. [CrossRef]

66. Hasell, D. Comunicación Abierta: Vital Para el Éxito del Negocio. Available online: http://www. amamex.org.mx/articulos/Comunicacion_Abierta_Vital_para_el_exito_del_negocio.html (accessed on 15 November 2016).

67. Ethugala, C.V. Expectations of the Private and Civil Stakeholders Responsiveness of the State Sector: Tea Industry of Sri Lanka. J. Asia Pac. Bus. Innov. Technol. Manag. 2011, 1, 13-19.

68. Matson, P.A.; Vitousek, P.M. Agricultural Intensification: Will Land Spared from Farming be Land Spared for Nature? Conserv. Biol. 2006, 20, 709-710. [CrossRef] [PubMed] 
69. Meena, V.S.; Meena, S.K.; Bisht, J.K.; Pattanayak, A. Conservation agricultural practices in sustainable food production. J. Clean. Prod. 2016, 137, 690-691. [CrossRef]

70. Kanchiswamy, C.N.; Malnoy, M.; Maffei, M.E. Chemical diversity of microbial volatiles and their potential for plant growth and productivity. Front. Plant Sci. 2015, 6, 1-23. [CrossRef] [PubMed]

71. Söderlund, J.; Bredin, K. HRM in project-intensive firms: Changes and challenges. Hum. Resour. Manag. 2006, 45, 249-265. [CrossRef]

72. Aon Hewitt. 2015 Trends in Global Employee Engagement; Aon Hewitt: Lincolnshire, IL, USA, 2015.

73. Paauwe, J. HRM and Performance: Achieving Long-Term Viability; Oxford University Press: Oxford, UK, 2004; ISBN 9780199273911.

74. Ostrom, E. Governing the Commons: The Evolution of Institutions for Collective Action; Cambridge University Press: Cambridge, UK, 2015; ISBN 10-1107569788.

75. García, J.; Vía, J.; Xirinacs, L.M. La Dimensión Cooperativa: Economía Solidaria y Transformación Social, 237th ed.; Economía Solidaria y Transformación Social; Icaria: Barcelona, Spain, 2006; ISBN 9788474268430.

76. Pretty, J.; Ward, H. Migration, Social Capital and the Environment. World Dev. 2001, 29, 209-227. [CrossRef]

77. Schumpeter, J.A. Capitalism, Socialism, and Democracy. (Original Work Published 1943); Routledge: Abingdon, UK, 2013; ISBN 9781134841516.

78. Fleitman, J. Negocios Exitosos: Cómo Empezar, Administrar y Operar Eficientemente un Negocio; McGraw-Hill, Ed.; McGraw-Hill: Ciudad de México, México, 2000; ISBN 9789701026946.

79. ISO. Sistemas de Gestión de la Calidad-Fundamentos y Vocabulario; ISO 9000; International Organization for Standarization: Geneva, Switzerland, 2005.

80. ISO. Sistemas de Gestión de la Calidad-Requisitos; ISO 9001; International Organization for Standarization: Geneva, Switzerland, 2015.

81. Plaza, M. Modelo Para la Gestión Estratégica de la Calidad Total: Aplicación a la Empresa Agroalimentaria; Escuela de Organización Industrial, Ed.; Colección EOI Empresas; EOI Empresa: Madrid, Spain, 2003; ISBN 10-848872344X.

82. IPMA ICB. Individual Competence Baseline for Project, Programme \& Portfolio Management -ICB, 4th ed.; International Project Management Association: Nijkerk, The Netherlands, 2015; ISBN 978-94-92338-01-3.

83. Reyes, J.; Martínez-Almela, J. Procesos de Proyectos y Competencias en Dirección de Proyectos; IPMA-LATNET: Ciudad de Panamá, Panamá, 2012; ISBN 978-84-616-4780-7.

84. Huemann, M.; Keegan, A.E.; Turner, R. Human resource management in the project-oriented company: A review. Int. J. Proj. Manag. 2007, 25, 315-323. [CrossRef]

85. Golini, R.; Kalchschmidt, M.; Landoni, P. Adoption of project management practices: The impact on international development projects of non-governmental organizations. Int. J. Proj. Manag. 2015, 33, 650-663. [CrossRef]

86. Ika, L.A.; Diallo, A.; Thuillier, D. Project management in the international development industry. Int. J. Manag. Proj. Bus. 2010, 3, 61-93. [CrossRef]

87. Papke-Shields, K.E.; Beise, C.; Quan, J. Do project managers practice what they preach, and does it matter to project success? Int. J. Proj. Manag. 2010, 28, 650-662. [CrossRef]

88. Drucker, P. Plan de Sucesión. Boletín Gobierno Corporativo; Deloitte: New York, NY, USA, 2010.

89. Huemann, M. Considering Human Resource Management when developing a project-oriented company: Case study of a telecommunication company. Int. J. Proj. Manag. 2010, 28, 361-369. [CrossRef]

90. Langreo, A. Las organización empresariales en el sector agroalimentario español. In El Sector Agro-MarAlimentario Español: Una Visión Renovada; Mediterráneo Económico; Cajamar Caja Rural: Almería, Spain, 2015; pp. 89-118.

91. Kwak, Y.H.; Sadatsafavi, H.; Walewski, J.; Williams, N.L. Evolution of project based organization: A case study. Int. J. Proj. Manag. 2015, 33, 1652-1664. [CrossRef]

92. Ulrich, D. Human Resource Champions: The New Agenda for Adding Value and Delivering Results; Harvard Business School Press: Boston, MA, USA, 2013; ISBN 9781422160695. 
93. Wagner, R.F. The Chief Project Officer (CPO)—A New Role for Project-Oriented Organisations. Available online: http:/ /blog.ipma.world/chief-project-officer-cpo-new-role-project-oriented-organisations / (accessed on 1 January 2017).

94. Hobbs, B.; Aubry, M.; Thuillier, D. The project management office as an organisational innovation. Int. J. Proj. Manag. 2008, 26, 547-555. [CrossRef] 